\title{
Brown adipose tissue is associated with systemic concentrations of peptides secreted from the gastrointestinal system and involved in appetite regulation
}

\author{
Maria Chondronikola 1,2,3,4, Craig Porter ${ }^{1,5}$, Ioannis Malagaris ${ }^{1,2}$, Aikaterini A Nella ${ }^{1,6}$ \\ and Labros S Sidossis ${ }^{1,2,4,5,7}$ \\ ${ }^{1}$ Metabolism Unit, Shriners Hospitals for Children-Galveston, Galveston, Texas, USA, ${ }^{2}$ Division of Rehabilitation \\ Sciences, Department of Nutrition and Metabolism, University of Texas Medical Branch, Galveston, Texas, USA, \\ ${ }^{3}$ Center for Human Nutrition and Atkins Center of Excellence in Obesity Medicine, Washington University School of \\ Medicine, St Louis, Missouri, USA, ${ }^{4}$ Department of Nutrition and Dietetics, Harokopio University, Athens, Greece, \\ ${ }^{5}$ Department of Surgery, ${ }^{6}$ Division of Pediatric Endocrinology, Department of Pediatrics, University of Texas Medical \\ Branch, Galveston, Texas, USA, and ${ }^{7}$ Department of Kinesiology and Health, Rutgers University, New Brunswick, \\ New Jersey, USA
}

\author{
Correspondence \\ should be addressed \\ to L S Sidossis \\ Email \\ Iss133@rci.rutgers.edu
}

\begin{abstract}
Objective: Brown adipose tissue (BAT) has been proposed as a potential therapeutic target against obesity and its related metabolic conditions. Data from studies in rodents support a cross talk between BAT and other distal tissues. The relation between BAT and peptide hormones secreted from the gastrointestinal system (GI) and involved in appetite regulation is not known in humans.

Design: We studied 18 men during thermoneutral conditions and mild non-shivering cold exposure (CE).

Methods: 2-Deoxy-2-( $\left.{ }^{18} \mathrm{~F}\right)$ fluoro-D-glucose positron emission tomography-computed tomography scans were conducted after mild cold to measure BAT volume. Fasting serum concentration of $\mathrm{Gl}$-secreted peptides and peptides involved in appetite regulation were measured during thermoneutral conditions and mild CE.

Results: During thermoneutral conditions, BAT volume was associated with lower serum concentration of leptin $(P=0.006)$, gastric inhibitory polypeptide $(P=0.016)$ and glucagon $(P=0.048)$ after adjusting for age and body fat percent. CE significantly decreased serum leptin $(P=0.004)$ and glucagon concentration $(P=0.020)$, while cold-induced BAT activation was significantly associated with lower serum ghrelin concentration $(P=0.029)$.

Conclusions: BAT is associated with systemic concentrations of Gl-secreted peptides and peptides involved in appetite regulation, suggesting a potential cross talk between BAT and the enteropancreatic axis. Further studies are needed to elucidate the potential link of BAT with the postprandial levels of appetite-regulating peptides and the putative role of BAT in appetite regulation in humans.
\end{abstract}

\section{Introduction}

Brown adipose tissue (BAT), a recently rediscovered tissue in humans $(1,2,3,4)$, has been proposed as a putative target for interventions against obesity and its associated metabolic perturbations (5). Thermogenesis via uncoupling protein 1 (UCP1) in response to various
() 2017 European Society of Endocrinology Printed in Great Britain
European Journal of Endocrinology

(2017) 177, 33-40 
higher amounts of BAT are associated with leanness and metabolic health in people $(1,8,9)$, whereas coldinduced BAT activation has been linked to increased energy expenditure, accelerated lipid mobilization and oxidation, glucose disposal and insulin sensitivity $(3,10,11,12,13,14,15)$.

Data from studies in rodents demonstrate that numerous circulating peptides affect BAT metabolic regulation, whereas BAT (sometimes referred to as the 'intrascapular gland') (16) secretes signaling molecules that may affect metabolic regulation in other tissues $(6,17)$. Studies in people have also reported the effect of thyroid hormones $(18,19)$, beta-adrenergic agonists $(20)$, glucocorticoids (21) and insulin (22) on BAT metabolism, whereas data from rodent studies support a link between BAT and peptides secreted from the gastrointestinal system (GI) involved in appetite regulation $(6,17,23)$. However, the relation (if any) between BAT and key peptides involved in energy homeostasis and appetite regulation is not known in humans.

To address this, we studied 18 men during thermoneutral conditions and mild cold exposure (CE). We hypothesized that BAT would be associated with lower systemic concentrations of leptin, ghrelin and glucagon (peptides linked to impaired BAT function and/or lower BAT levels). Our findings support that, independent of age and adiposity, BAT volume was significantly associated with lower serum concentrations of leptin, gastric inhibitory polypeptide (GIP) and glucagon during thermoneutrality. When mild CE was used to activate BAT thermogenesis, serum leptin and glucagon concentration decreased compared to thermoneutral conditions. Moreover, BAT volume was associated with greater suppression in serum ghrelin concentration during CE, which was independent of age and adiposity. Overall, these results support a link between BAT and key GI and adipose tissue-secreted peptides involved in appetite regulation and energy homeostasis, suggesting a potential endocrine role for BAT in humans.

\section{Subjects and methods}

\section{Subjects}

Eighteen men (age $47.6 \pm 17.8$ years, BMI $29.7 \pm 4.9 \mathrm{~kg} / \mathrm{m}^{2}$ ) were enrolled in the study. Table 1 contains the descriptive characteristics of the participants. Outcomes related to glucose metabolism, insulin sensitivity, free fatty acid kinetics and thermoregulation have been previously
Table 1 Subject characteristics.

\begin{tabular}{lll}
\hline Parameters & Mean \pm s.D. \\
\cline { 1 - 1 } Age (years) & $47.6 \pm 17.8$ \\
BMI $\left(\mathrm{kg} / \mathrm{m}^{2}\right)$ & $29.7 \pm 4.9$ \\
Lean mass $(\mathrm{kg})$ & $61.9 \pm 8.3$ \\
Body fat $(\%)$ & $32.4 \pm 9.1$ \\
BAT volume $(\mathrm{mL})$ & $33.9 \pm 43.3$ \\
BAT SUV & $1.67 \pm 0.99$ \\
Plasma glucose $(\mathrm{g} / \mathrm{mL})$ & $97.8 \pm 8.4$ \\
Serum insulin $(\mu \mathrm{U} / \mathrm{mL})$ & $8.4 \pm 5.7$ \\
\hline
\end{tabular}

BAT, brown adipose tissue; BMI, body mass index; SUV $_{\text {mean }}$ mean standardized uptake value.

reported (NCT01791114) (11, 15, 24). Study participants were screened for health status, smoking, alcohol or drug use, and recent medication or supplement use. Individuals with acute illness or/and major chronic disease were excluded. Informed written consent was obtained prior to study enrolment from all participants in accordance with the Declaration of Helsinki. The University of Texas Medical Branch (UTMB) Institutional Review Board and Institute for Translational Sciences (ITS) Scientific Review Committee approved the experimental protocol. The study participants were enrolled from January 2012 until April 2015.

\section{Experimental protocol}

Each participant completed one CE study and one thermoneutral study, approximately two weeks apart. Three days before the study, participants were asked to follow a weight-maintaining diet and also refrain from excessive physical activity and consumption of alcohol and caffeine. The evening before each study, subjects were admitted to the ITS Clinical Research Center at UTMB and offered a standardized meal. Subjects fasted and rested in bed overnight, wearing standardized clothing (a T-shirt and a pair of shorts). During the CE study, the following morning, a 6-h individualized CE protocol was employed to induce non-shivering thermogenesis as previously described (11). Briefly, during CE, subjects wore garments cooled by liquid circulation (Cool Flow vest and blanket and Arctic Chiller cooling system, Polar Products Inc., Stow, OH, USA) and laid supine. The temperatures of the cooling garments and the room were initially set at approximately $19-20^{\circ} \mathrm{C}$ and were decreased until subjects reported shivering. Then, cooling garment and ambient temperatures were increased by $1^{\circ} \mathrm{C}$ and adjusted as needed to prevent shivering. During the thermoneutral study, the participants wore the same standardized 
clothing, and the ambient room temperature was kept at $25-27^{\circ} \mathrm{C}$.

\section{Positron emission tomography-computerized tomography (PET-CT)}

After $5 \mathrm{~h}$ of $\mathrm{CE}$, subjects were given a bolus injection of $185 \mathrm{MBq}$ of 2-deoxy-2-( $\left.{ }^{18} \mathrm{~F}\right)$ fluoro-D-glucose $\left({ }^{18} \mathrm{~F}-\mathrm{FDG}\right)$. One hour later, a positron emission tomographycomputed tomography (PET-CT) (General Electric Medical Systems, Milwaukee, WI, USA) scan was performed to assess BAT volume $(\mathrm{mL})$ and mean standardized uptake value (SUV; $\mathrm{g} / \mathrm{mL}$ ). We assessed the PET-CT scans for ${ }^{18} \mathrm{~F}-\mathrm{FDG}$ BAT using the following criteria: (a) ${ }^{18} \mathrm{~F}-\mathrm{FDG}$ uptake was evident in the cervicalsupraclavicular, mediastinal, paravertebral and/or perirenal areas; (b) ${ }^{18} \mathrm{~F}$-FDG uptake had a mean SUV of 1.5 or greater (an indicator of ${ }^{18} \mathrm{~F}-\mathrm{FDG}$ uptake intensity) and (c) the tissue corresponded to the density of adipose tissue on CT ( -190 to -30 Hounsfield units). The mean SUVs for each identified deposit were determined using commercial fusion software (MIM software; MIMvista Corp., Cleveland, OH, USA). The volume of ${ }^{18} \mathrm{~F}$-FDG BAT was quantified by autocontouring each identified individual BAT deposit (with a SUV $\geq 1.5$ ).

\section{Body composition}

We used Dual X-ray Absorptiometry to evaluate the fat mass and fat free mass of the participants (Hologic model QDR-4500W, Hologic Inc., Bedford, MA, USA).

\section{Blood sample analysis}

Serum leptin (minimum detectable concentration (MinDC): $41 \mathrm{pg} / \mathrm{mL}$ ), active ghrelin (MinDC: $13 \mathrm{pg} / \mathrm{mL}$ ), gastric inhibitory peptide (GIP) (MinDC: $0.6 \mathrm{pg} / \mathrm{mL}$ ), active glucagon-like peptide 1 (GLP1) (MinDC: $1.2 \mathrm{pg} / \mathrm{mL}$ ), glucagon (MinDC: $13 \mathrm{pg} / \mathrm{mL}$ ), pancreatic polypeptide (PP) (MinDC: $2 \mathrm{pg} / \mathrm{mL}$ ) and peptide YY (PYY) (MinDC: $28 \mathrm{pg} / \mathrm{mL}$ ) were measured using a multiplex assay (Milliplex, Billerica, MA, USA). For samples with serum concentrations below the detectable levels of the assay, the upper limit of the detectable level was used in the statistical analysis. Intra- and interassay coefficients of variation were $<10 \%$ and $<15 \%$, respectively. Serum insulin concentrations were measured using chemiluminescence (Dxi 600 analyzer; Beckman Coulter, Pasadena, CA, USA) and plasma glucose concentrations were measured using an automated glucose analyzer (Yellow Spring Instruments, Yellow Springs, OH, USA).

\section{Statistical analysis}

Paired $t$-tests were used to compare the hormone levels between $\mathrm{CE}$ and thermoneutral conditions. Univariate and multivariate regression analyses were performed to evaluate the association of BAT volume with serum concentrations of the peptide hormones of interest. Multivariate linear regression modeled the relationship between each outcome and BAT volume, while adjusting for the potentially prognostic covariates of body fat percent and age. BAT volume was log-transformed for better centering and interpretation. The statistical analysis was performed using SPSS statistical software, version 23. All statistical tests assumed a 95\% level of confidence. Correction for multiple comparisons was not performed due to the small sample of the study.

\section{Results}

BAT is associated with lower serum concentrations of leptin, GIP and glucagon during thermoneutrality

We used univariate and multivariate analysis to identify the relationship of BAT volume with GI and adipocytesecreted peptides involved in appetite regulation and energy homeostasis during thermoneutral conditions (Table 2). By univariate analysis, BAT volume was associated with higher serum PYY $(P=0.013)$ and lower leptin $(P<0.001)$ and insulin concentrations $(P=0.025)$. On multivariate analysis, and after adjusting for body fat percentage and age, BAT volume was no longer associated with elevated PYY concentration, but it was significantly associated with lower serum leptin $(P=0.006)$, GIP $(P=0.016)$ and glucagon $(P=0.048)$ concentrations (Fig. 1A, B and C). Serum insulin concentration was marginally associated with BAT volume after adjusting for age and adiposity $(P=0.084)$.

\section{Mild CE decreases glucagon and leptin concentrations}

Decreasing ambient temperature has been proposed as a lifestyle intervention against metabolic abnormalities. Therefore, we exposed the study participants to mild, nonshivering cold and accessed the circulating concentrations of secreted peptides involved in the regulation of energy homeostasis and appetite regulation (Table 3). Five hours of CE significantly decreased serum leptin $(P=0.004)$ 
Table 2 Association between brown adipose tissue (BAT) volume with the systemic concentrations of peptides involved in energy homeostasis and appetite regulation during thermoneutrality.

Parameters
Ghrelin $(\mathrm{pg} / \mathrm{mL})$
Gastric inhibitory polypeptide $(\mathrm{pg} / \mathrm{mL})$
Glucagon $(\mathrm{pg} / \mathrm{mL})$
Glucagon-like peptide $1(\mathrm{pg} / \mathrm{mL})$
Leptin $(\mathrm{pg} / \mathrm{mL})$
Pancreatic polypeptide $(\mathrm{pg} / \mathrm{mL})$
Peptide $\mathrm{YY}(\mathrm{pg} / \mathrm{mL})$
Insulin $(\mu \mathrm{U} / \mathrm{mL})$

\begin{tabular}{c}
\hline Univariate \\
\hline Beta \pm S.E. \\
\hline $8.3 \pm 4.2$ \\
$-5.9 \pm 10.4$ \\
$-5.1 \pm 10.3$ \\
$1.9 \pm 4.3$ \\
$\mathbf{- 5 7 4 8} \pm \mathbf{1 2 0 4}$ \\
$-6.8 \pm 13.1$ \\
$\mathbf{5 2 . 8} \pm \mathbf{1 8 . 7}$ \\
$\mathbf{- 3 . 7} \pm \mathbf{1 . 5}$
\end{tabular}

\begin{tabular}{c}
\hline \\
\hline -value \\
\hline 0.067 \\
0.577 \\
0.630 \\
0.674 \\
$<\mathbf{0 . 0 0 1}$ \\
0.608 \\
$\mathbf{0 . 0 1 3}$ \\
$\mathbf{0 . 0 2 5}$
\end{tabular}

\begin{tabular}{c}
\hline Multivariate \\
\hline Beta \pm S.E. \\
\hline $12.2 \pm 6.3$ \\
$\mathbf{- 3 3 . 6} \pm \mathbf{1 2 . 3}$ \\
$\mathbf{- 2 6 . 7} \pm \mathbf{1 2 . 3}$ \\
$3.1 \pm 6.2$ \\
$\mathbf{- 4 4 6 7} \pm \mathbf{1 3 7 5}$ \\
$2.96 \pm 19.90$ \\
$38.6 \pm 28.5$ \\
$-4.1 \pm 2.1$
\end{tabular}

\begin{tabular}{l}
\hline P-value \\
\hline 0.074 \\
$\mathbf{0 . 0 1 6}$ \\
$\mathbf{0 . 0 4 8}$ \\
0.545 \\
$\mathbf{0 . 0 0 6}$ \\
0.884 \\
0.200 \\
0.084
\end{tabular}

For the multivariate regression, the estimates have been adjusted for age and $\%$ body fat. BAT volumes have been transformed as log (BAT volume +1 ). Values in bold font denote statistical significance.

and glucagon $(P=0.020)$ concentrations compared to thermoneutral conditions.

\section{BAT activation by CE is associated with decreases in serum ghrelin concentration}

Univariate and multivariate analyses were also used to identify the relation between BAT volume and change in peptide hormones during CE (Table 4). On univariate analysis, no positive or negative associations were found; however, multivariate analysis (after adjusting for age and body fat percentage) showed that BAT volume was associated with a greater suppression in serum ghrelin concentration with CE compared to thermoneutral conditions $(P=0.029)$ (Fig. 1D). There was no association between BAT volume and the cold-induced change in
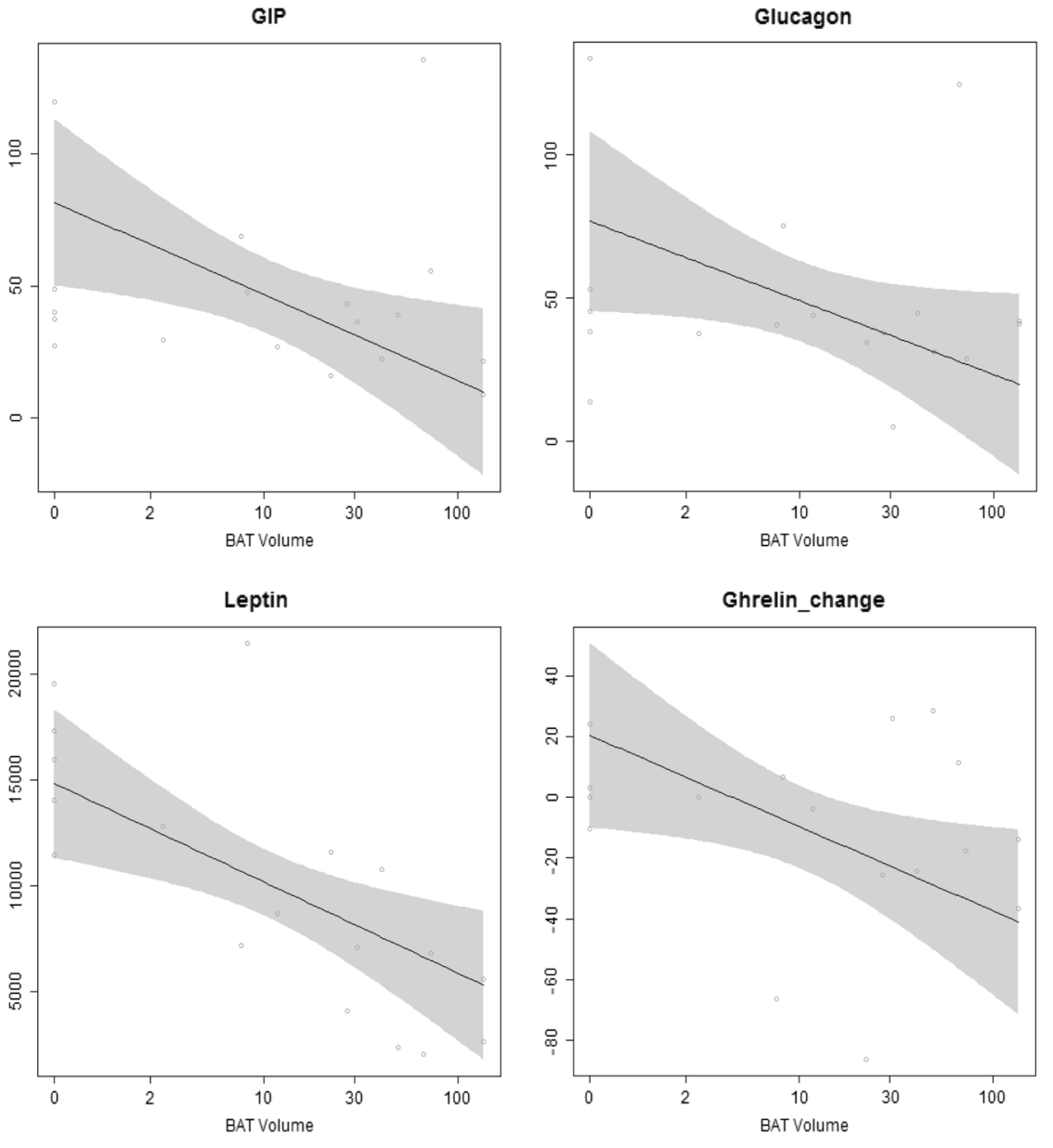

\section{Figure 1}

Association between BAT volume with the serum concentrations of peptides regulating energy homeostasis and appetite. (A, B and C) Association of BAT volume with the serum concentration of $(A)$ gastric inhibitory peptide (GIP) $(P=0.016)$, (B) glucagon $(P=0.048)$ and (C) leptin $(P=0.006)$ adjusted for age and body fat percent during thermoneutral conditions. (D) Association of BAT volume with the change in serum ghrelin concentration adjusted for age and percent body fat in response to cold exposure $(P=0.029)$. 
Table 3 Systemic concentrations of secreted peptides regulating energy homeostasis during thermoneutral (TN) and cold exposure (CE) conditions and their change between the two conditions. Data are presented as mean \pm S.D. Absolute values represent the serum concentrations in the 5-h CE and TN metabolic studies.

\begin{tabular}{l} 
Parameters \\
\hline Ghrelin $(\mathrm{pg} / \mathrm{mL})$ \\
Gastric inhibitory polypeptide $(\mathrm{pg} / \mathrm{mL})$ \\
Glucagon-like peptide $1(\mathrm{pg} / \mathrm{mL})$ \\
Glucagon $(\mathrm{pg} / \mathrm{mL})$ \\
Leptin $(\mathrm{pg} / \mathrm{mL})$ \\
Pancreatic polypeptide $(\mathrm{pg} / \mathrm{mL})$ \\
Peptide $\mathrm{YY}(\mathrm{pg} / \mathrm{mL})$ \\
Insulin $(\mu \mathrm{U} / \mathrm{mL})$
\end{tabular}

\begin{tabular}{c}
\hline TN \\
\hline $38.0 \pm 42.2$ \\
$33.0 \pm 25.0$ \\
$15.6 \pm 12.6$ \\
$\mathbf{4 2 . 2} \pm \mathbf{2 8 . 3}$ \\
$\mathbf{8 3 7 9} \pm \mathbf{5 1 5 3}$ \\
$67.2 \pm 63.9$ \\
$65.4 \pm 51.2$ \\
$5.1 \pm 3.8$ \\
\hline
\end{tabular}

\begin{tabular}{c} 
CE \\
\hline $27.7 \pm 26.2$ \\
$35.5 \pm 24.1$ \\
$17.7 \pm 17.2$ \\
$\mathbf{3 4 . 5} \pm \mathbf{2 6 . 6}$ \\
$\mathbf{6 5 8 0} \pm \mathbf{4 2 8 9}$ \\
$55.5 \pm 44.6$ \\
$55.5 \pm 40.6$ \\
$4.7 \pm 2.7$ \\
\hline
\end{tabular}

\begin{tabular}{c}
\hline Paired change \\
\hline$-10.3 \pm 30.1$ \\
$-2.5 \pm 18.4$ \\
$2.1 \pm 10.6$ \\
$-\mathbf{7 . 7} \pm \mathbf{1 2 . 8}$ \\
$\mathbf{- 1 7 9 9} \pm \mathbf{2 2 8 0}$ \\
$-11.7 \pm 62.3$ \\
$-10.0 \pm 22.9$ \\
$-0.8 \pm 2.4$ \\
\hline
\end{tabular}

\begin{tabular}{c}
\hline P-value \\
\hline 0.165 \\
0.571 \\
0.420 \\
$\mathbf{0 . 0 2 0}$ \\
$\mathbf{0 . 0 0 4}$ \\
0.436 \\
0.101 \\
0.359 \\
\hline
\end{tabular}

Values in bold font denote statistical significance.

serum insulin, GIP, glucagon, GLP1, leptin, PYY or PP concentrations.

\section{Discussion}

We report evidence supporting a link between BAT and the systemic concentrations of GI tract and adiposesecreted peptides involved in appetite regulation and energy metabolism in people. Specifically, BAT volume was associated with lower serum glucagon, leptin and GIP concentrations independent of age and adiposity during thermoneutral conditions. BAT volume was also associated with a greater suppression in serum ghrelin concentration with CE. Finally, CE was associated with decreased serum concentrations of leptin and glucagon. Collectively, these results further define the role of BAT in metabolic regulation by suggesting a potential endocrine role of BAT in humans.

Our study is the first to report a link between BAT and, the orexigenic gut hormone (25), ghrelin in humans. BAT volume was associated with the suppression in serum ghrelin concentration with $\mathrm{CE}$; during thermoneutrality,
BAT was only marginally associated with elevated serum ghrelin. These findings might suggest a potential role of BAT activation in appetite regulation and a possible interventional target in patients with obesity in whom lower fasting ghrelin concentrations $(26,27)$ and a blunted postprandial suppression in systemic ghrelin concentration $(26,28)$ are typically seen and thought to contribute to dysregulated energy intake. In addition, data from studies in preclinical models also support the link between BAT and ghrelin. BAT expresses the growth hormone secretagogue receptor via which ghrelin exerts its action in adipocytes $(29,30)$, whereas ghrelin has been shown to impair BAT function in rodents $(23,31)$. These results suggest a link between the systemic ghrelin concentration and BAT activity in people. Future, mechanistic studies are needed to establish link between ghrelin and BAT function in people.

Inthisstudy, BATvolumewasassociated withlowerserum GIP concentration during thermoneutrality independent of age and adiposity. GIP is another gut-derived hormone (32), which has been reported to play a role in adipose tissue function in rodents. Elevated GIP levels have been previously associated with obesity $(33,34)$, but information

Table 4 Association between brown adipose tissue (BAT) volume and the cold-induced change in the concentration of systemic peptides regulating energy homeostasis and appetite regulation.

\begin{tabular}{|c|c|c|c|c|}
\hline & Univariate & & Multivariate & \\
\hline Parameters & Beta \pm S.E. & $P$-value & Beta \pm S.E. & $P$-value \\
\hline Ghrelin (pg/mL) & $-8.3 \pm 9.3$ & 0.381 & $-28.8 \pm 11.9$ & 0.029 \\
\hline Gastric inhibitory polypeptide (pg/mL) & $2.1 \pm 5.7$ & 0.719 & $5.1 \pm 8.8$ & 0.570 \\
\hline Glucagon $(\mathrm{pg} / \mathrm{mL})$ & $-0.2 \pm 4.0$ & 0.955 & $5.0 \pm 4.9$ & 0.325 \\
\hline Glucagon-like peptide 1 (pg/mL) & $3.4 \pm 3.2$ & 0.308 & $0.6 \pm 6.2$ & 0.927 \\
\hline Leptin $(\mathrm{pg} / \mathrm{mL})$ & $758 \pm 694$ & 0.291 & $1591 \pm 978$ & 0.126 \\
\hline Pancreatic polypeptide (pg/mL) & $20.1 \pm 19.0$ & 0.307 & $46.3 \pm 25.7$ & 0.093 \\
\hline Peptide YY (pg/mL) & $-8.3 \pm 7.4$ & 0.281 & $2.2 \pm 10.7$ & 0.842 \\
\hline Insulin $(\mu \mathrm{U} / \mathrm{mL})$ & $-0.7 \pm 1.4$ & 0.376 & $-1.5 \pm 2.1$ & 0.478 \\
\hline
\end{tabular}

The estimates have been adjusted for age and \% body fat in the multivariate regression. BAT volumes have been transformed as log (BAT volume +1 ). Values in bold font denote statistical significance. 
on their relationship to BAT function is sparse. In rodents, cold acclimation increased BAT mass relative to body weight and the intestinal concentration of GIP (35). Adipocytes express the GIP receptor (36), while GIP has been shown to promote fatty acid synthesis and to inhibit the isoprotenolinduced lipolysis $(37,38)$. Considering the importance of lipolysis for BAT thermogenesis $(6,15)$, it is likely that high fasting serum GIP may promote excessive fat accumulation and/or decreased lipolysis in response to the adrenergic stimuli leading to impaired BAT metabolic function. Interestingly, we have previously reported that BAT volume is associated with greater adipose tissue lipolysis with cold (15). Whether the circulating GIP levels mediate the link between BAT and the cold-induced lipolysis remains to be determined.

The results of this study also support the relation of BAT with the systemic concentration of the adipokine leptin. We found a significant association between BAT and lower serum leptin concentration during thermoneutral conditions independent of age and adiposity, and a further decrease in serum leptin concentration during CE. Similarly, Lee et al. previously reported that coldacclimated BAT was inversely correlated with coldinduced changes in leptin concentrations in young lean adults (10). Additionally, data from studies in preclinical models support the relation of BAT with leptin. Namely, CE suppresses leptin production in brown adipocytes (39), while BAT atrophy increases leptin secretion (6). Considering the current literature on the link of leptin with BAT, our findings suggest that cold-induced BAT activation may alleviate 'leptin resistance' in participants with overweight/obesity.

Moreover, our results support the relation of BAT with serum glucagon concentration. Specifically, we found that lower serum glucagon concentration is associated with higher BAT volume during thermoneutrality after adjustment for age and adiposity, and that it further decreases during exposure to mild cold. Glucagon plays a major role in the regulation of blood glucose concentration by regulating hepatic glucose production (40). Human studies also support the role of glucagon in appetite regulation (41). Consistent with our results, data from studies in rodents have shown that BAT transplantation leads to decreased circulating glucagon concentration (42). The mechanisms explaining the link between glucagon and BAT are currently unknown.

BAT activation increases energy expenditure $(3,14,24)$ to produce heat and, thus, BAT has attracted significant interest as a target tissue for the treatment of obesity.
Interventions that increase energy expenditure and induce an isocaloric increase in food intake are unlikely to be effective for weight loss. The current evidence on the role of BAT in appetite regulation and food intake is unclear. Although CE increases food intake in rodents, the cold-exposed rodents have significantly lower body weight compared to animals kept in room temperature conditions (35). In humans, Lee et al. reported a trend for increased appetite in a small group of young lean individuals with CE (10), while Yoneshiro et al. reported that cold acclimation increased BAT activity and decreased body fat in healthy adults (43). These results suggest that the cold-related increase in food intake may not fully compensate for the increased energy expenditure due to thermogenesis. Moreover, numerous peptides that affect appetite also affect BAT activity (as previously described), while changes in nutrient availability due to BAT activation may affect the appetite (44). Future studies are needed to systematically investigate the role of BAT in appetite regulation and food intake and clarify the potential underlying mechanisms.

Here, we report the link of BAT with secreted peptides from the enteropancreatic axis (ghrelin, glucagon and GIP) and the adipokine leptin. Although these observations are cross sectional and collected from a small sample of participants, they might suggest a potential cross talk between BAT and other tissues regulating energy homeostasis. Further mechanistic studies are needed to establish the relation of BAT with the appetite-regulating peptides and support the putative role of BAT in appetite regulation and food intake. Moreover, the sample of the study consisted of male participants only, and therefore, the generalizability of the study results in women remains to be determined.

In conclusion, this study shows that BAT volume is associated with lower serum concentration of leptin, GIP and glucagon after adjusting for age and body fat percent, while BAT was significantly associated with a greater suppression in ghrelin serum concentration with CE. Finally, non-shivering CE significantly decreased serum leptin and glucagon concentrations compared to thermoneutrality. Overall, these results support a link between BAT and key GI and adipose tissue-secreted peptides involved in appetite regulation and energy homeostasis, suggesting a potential endocrine role for BAT in humans. The mechanism(s) via which BAT exerts its metabolic effects systematically remain to be fully understood. Meanwhile, a cross talk between BAT and other metabolically active tissues might partially explain the role of BAT in systemic metabolic regulation. 


\section{Declaration of interest}

The authors declare that there is no conflict of interest that could be perceived as prejudicing the impartiality of this study.

\section{Funding}

This study was conducted with the support of the Institute for Translational Sciences at the University of Texas Medical Branch, supported in part by a Clinical and Translational Science Award (UL1TR000071) from the National Center for Advancing Translational Sciences, the National Institutes of Health, the American Diabetes Association (1-14-TS-35), Shriners Hospitals for Children grants $(84090,85310)$, the John Sealy Memorial Endowment Fund for Biomedical Research (66992), the Claude Pepper Older Americans Independence Center (P30 AG024832) and the Sealy Center on Aging. M C was funded by the Alexander S Onassis Public Benefit Foundation.

\section{Acknowledgements}

The authors want to thank the study participants and the nursing and administrative personnel at the Institute of Translational Sciences Clinical Research Center at the University of Texas Medical Branch. The authors acknowledge the editorial assistance of Sarah Toombs Smith, University of Texas Medical Branch. We also thank Elena Volpi, Palam Annamalai and Fernardo Cessani, University of Texas Medical Branch, for the medical coverage of the study. Rajesh Kumar, University of Texas Medical Branch for performing the PET/CT scans; Sebastien M Labbe, Quebec Heart and Lung Research Institute Centre for the BAT assessment using PET/CT imaging; Manish $\mathrm{K}$ Saraf and John $\mathrm{O}$ Ogunbilege, University of Texas Medical Branch, for measuring the concentrations of serum peptide hormones. The study was registered at clinicaltrials.gov (NCT01791114). We also thank Elisabet Borsheim, Christina Yfanti and Nicholas M Hurren, University of Texas Medical Branch, for their assistance with performing the clinical studies.

\section{References}

1 Cypess AM, Lehman S, Williams G, Tal I, Rodman D, Goldfine AB, Kuo FC, Palmer EL, Tseng YH, Doria A et al. Identification and importance of brown adipose tissue in adult humans. New England Journal of Medicine 2009360 1509-1517. (doi:10.1056/ NEJMoa0810780)

2 Virtanen KA, Lidell ME, Orava J, Heglind M, Westergren R, Niemi T, Taittonen M, Laine J, Savisto NJ, Enerback S et al. Functional brown adipose tissue in healthy adults. New England Journal of Medicine 2009 360 1518-1525. (doi:10.1056/NEJMoa0808949)

3 van Marken Lichtenbelt WD, Vanhommerig JW, Smulders NM, Drossaerts JM, Kemerink GJ, Bouvy ND, Schrauwen P \& Teule GJ. Cold-activated brown adipose tissue in healthy men. New England Journal of Medicine 2009360 1500-1508. (doi:10.1056/ NEJMoa0808718)

4 Nedergaard J, Bengtsson T \& Cannon B. Unexpected evidence for active brown adipose tissue in adult humans. American Journal of Physiology: Endocrinology and Metabolism 2007293 E444-E452. (doi:10.1152/ajpendo.00691.2006)

5 Porter C, Chondronikola M \& Sidossis LS. The therapeutic potential of brown adipocytes in humans. Frontiers in Endocrinology 20156156. (doi:10.3389/fendo.2015.00156)

6 Cannon B \& Nedergaard J. Brown adipose tissue: function and physiological significance. Physiological Reviews 200484 277-359. (doi:10.1152/physrev.00015.2003)

7 Kajimura S, Spiegelman BM \& Seale P. Brown and beige fat: physiological roles beyond heat generation. Cell Metabolism 201522 546-559. (doi:10.1016/j.cmet.2015.09.007)
8 Matsushita M, Yoneshiro T, Aita S, Kameya T, Sugie H \& Saito M. Impact of brown adipose tissue on body fatness and glucose metabolism in healthy humans. International Journal of Obesity 2014 38 812-817. (doi:10.1038/ijo.2013.206)

9 Ouellet V, Routhier-Labadie A, Bellemare W, Lakhal-Chaieb L, Turcotte E, Carpentier AC \& Richard D. Outdoor temperature, age, sex, body mass index, and diabetic status determine the prevalence, mass, and glucose-uptake activity of 18F-FDG-detected BAT in humans. Journal of Clinical Endocrinology and Metabolism 201196 192-199. (doi:10.1210/jc.2010-0989)

10 Lee P, Smith S, Linderman J, Courville AB, Brychta RJ, Dieckmann W, Werner CD, Chen KY \& Celi FS. Temperature-acclimated brown adipose tissue modulates insulin sensitivity in humans. Diabetes 2014 63 3686-3698. (doi:10.2337/db14-0513)

11 Chondronikola M, Volpi E, Borsheim E, Porter C, Annamalai P, Enerback S, Lidell ME, Saraf MK, Labbe SM, Hurren NM et al. Brown adipose tissue improves whole-body glucose homeostasis and insulin sensitivity in humans. Diabetes 201463 4089-4099. (doi:10.2337/ db14-0746)

12 Ouellet V, Labbe SM, Blondin DP, Phoenix S, Guerin B, Haman F, Turcotte EE, Richard D \& Carpentier AC. Brown adipose tissue oxidative metabolism contributes to energy expenditure during acute cold exposure in humans. Journal of Clinical Investigation 2012122 545-552. (doi:10.1172/JCI60433)

13 Blondin DP, Labbe SM, Phoenix S, Guerin B, Turcotte EE, Richard D, Carpentier AC \& Haman F. Contributions of white and brown adipose tissues and skeletal muscles to acute cold-induced metabolic responses in healthy men. Journal of Physiology 2015593 701-714. (doi:10.1113/jphysiol.2014.283598)

14 Yoneshiro T, Aita S, Matsushita M, Kameya T, Nakada K, Kawai Y $\&$ Saito M. Brown adipose tissue, whole-body energy expenditure, and thermogenesis in healthy adult men. Obesity 2011 19 13-16. (doi:10.1038/oby.2010.105)

15 Chondronikola M, Volpi E, Borsheim E, Porter C, Saraf MK, Annamalai P, Yfanti C, Chao T, Wong D, Shinoda K et al. Brown adipose tissue activation is linked to distinct systemic effects on lipid metabolism in humans. Cell Metabolism 201623 1200-1206. (doi:10.1016/j.cmet.2016.04.029)

16 Bonnot E. The interscapular gland. Journal of Anatomy and Physiology 190843 43-58. (doi:10.1016/s0140-6736(01)62853-8)

17 Villarroya F, Cereijo R, Villarroya J \& Giralt M. Brown adipose tissue as a secretory organ. Nature Reviews Endocrinology 201613 26-35. (doi:10.1038/nrendo.2016.136)

18 Broeders EP, Vijgen GH, Havekes B, Bouvy ND, Mottaghy FM, Kars M, Schaper NC, Schrauwen P, Brans B \& van Marken Lichtenbelt WD. Thyroid hormone activates brown adipose tissue and increases non-shivering thermogenesis - a cohort study in a group of thyroid carcinoma patients. PLOS ONE 201611 e0145049. (doi:10.1371/ journal.pone.0145049)

19 Lahesmaa M, Orava J, Schalin-Jantti C, Soinio M, Hannukainen JC, Noponen T, Kirjavainen A, Iida H, Kudomi N, Enerback S et al. Hyperthyroidism increases brown fat metabolism in humans. Journal of Clinical Endocrinology and Metabolism 201499 E28-E35. (doi:10.1210/jc.2013-2312)

20 Cypess AM, Weiner LS, Roberts-Toler C, Elia EF, Kessler SH, Kahn PA, English J, Chatman K, Trauger SA, Doria A et al. Activation of human brown adipose tissue by a beta3-adrenergic receptor agonist. Cell Metabolism 201521 33-38. (doi:10.1016/j. cmet.2014.12.009)

21 Ramage LE, Akyol M, Fletcher AM, Forsythe J, Nixon M, Carter RN, van Beek EJ, Morton NM, Walker BR \& Stimson RH. Glucocorticoids acutely increase brown adipose tissue activity in humans, revealing species-specific differences in UCP-1 regulation. Cell Metabolism 2016 24 130-141. (doi:10.1016/j.cmet.2016.06.011)

22 Orava J, Nuutila P, Noponen T, Parkkola R, Viljanen T, Enerback S, Rissanen A, Pietilainen KH \& Virtanen KA. Blunted metabolic 
responses to cold and insulin stimulation in brown adipose tissue of obese humans. Obesity 201321 2279-2287. (doi:10.1002/oby.20456)

23 Mano-Otagiri A, Ohata H, Iwasaki-Sekino A, Nemoto T \& Shibasaki T. Ghrelin suppresses noradrenaline release in the brown adipose tissue of rats. Journal of Endocrinology 2009201 341-349. (doi:10.1677/JOE08-0374)

24 Chondronikola M, Volpi E, Borsheim E, Chao T, Porter C, Annamalai P, Yfanti C, Labbe SM, Hurren NM, Malagaris I et al. Brown adipose tissue is linked to a distinct thermoregulatory response to mild cold in people. Frontiers in Physiology 20167 129. (doi:10.3389/ fphys.2016.00129)

25 Zigman JM, Bouret SG \& Andrews ZB. Obesity impairs the action of the neuroendocrine ghrelin system. Trends in Endocrinology and Metabolism 201627 54-63. (doi:10.1016/j.tem.2015.09.010)

26 Tschöp M, Weyer C, Tataranni PA, Devanarayan V, Ravussin E \& Heiman ML. Circulating ghrelin levels are decreased in human obesity. Diabetes 200150 707-709. (doi:10.2337/diabetes.50.4.707)

27 Shiiya T, Nakazato M, Mizuta M, Date Y, Mondal MS, Tanaka M, Nozoe S-I, Hosoda H, Kangawa K \& Matsukura S. Plasma ghrelin levels in lean and obese humans and the effect of glucose on ghrelin secretion. Journal of Clinical Endocrinology and Metabolism 200287 240-244. (doi:10.1210/jcem.87.1.8129)

28 Cummings DE. Ghrelin and the short- and long-term regulation of appetite and body weight. Physiology and Behavior 200689 71-84. (doi:10.1016/j.physbeh.2006.05.022)

29 Kojima M, Hosoda H, Date Y, Nakazato M, Matsuo H \& Kangawa K. Ghrelin is a growth-hormone-releasing acylated peptide from stomach. Nature 1999402 656-660. (doi:10.1038/45230)

30 Sun Y, Garcia JM \& Smith RG. Ghrelin and growth hormone secretagogue receptor expression in mice during aging. Endocrinology 2007148 1323-1329. (doi:10.1210/en.2006-0782)

31 Lin L, Lee JH, Bongmba OY, Ma X, Zhu X, Sheikh-Hamad D \& Sun Y. The suppression of ghrelin signaling mitigates age-associated thermogenic impairment. Aging 20146 1019-1032. (doi:10.18632/ aging.100706)

32 Drucker DJ. The biology of incretin hormones. Cell Metabolism 20063 153-165. (doi:10.1016/j.cmet.2006.01.004)

33 Nasteska D, Harada N, Suzuki K, Yamane S, Hamasaki A, Joo E, Iwasaki K, Shibue K, Harada T \& Inagaki N. Chronic reduction of GIP secretion alleviates obesity and insulin resistance under high-fat diet conditions. Diabetes 201463 2332-2343. (doi:10.2337/db13-1563)
34 Miyawaki K, Yamada Y, Ban N, Ihara Y, Tsukiyama K, Zhou H, Fujimoto S, Oku A, Tsuda K, Toyokuni S et al. Inhibition of gastric inhibitory polypeptide signaling prevents obesity. Nature Medicine 20028 738-742. (doi:10.1038/nm727)

35 Irwin N, Francis JM \& Flatt PR. Alterations of glucose-dependent insulinotropic polypeptide (GIP) during cold acclimation. Regulatory Peptides 2011167 91-96. (doi:10.1016/j.regpep.2010.12.001)

36 Yip RG, Boylan MO, Kieffer TJ \& Wolfe MM. Functional GIP receptors are present on adipocytes. Endocrinology 1998139 4004-4007. (doi:10.1210/endo.139.9.6288)

37 Getty-Kaushik L, Song DH, Boylan MO, Corkey BE \& Wolfe MM. Glucose-dependent insulinotropic polypeptide modulates adipocyte lipolysis and reesterification. Obesity 200614 1124-1131. (doi:10.1038/oby.2006.129)

38 Oben J, Morgan L, Fletcher J \& Marks V. Effect of the enteropancreatic hormones, gastric inhibitory polypeptide and glucagonlike polypeptide-1(7-36) amide, on fatty acid synthesis in explants of rat adipose tissue. Journal of Endocrinology 1991130 267-272. (doi:10.1677/joe.0.1300267)

39 Evans BA, Agar L \& Summers RJ. The role of the sympathetic nervous system in the regulation of leptin synthesis in C57BL/6 mice. FEBS Letters 1999444 149-154. (doi:10.1016/S0014-5793(99)00049-6)

40 Del Prato S, Castellino P, Simonson DC \& DeFronzo RA Hyperglucagonemia and insulin-mediated glucose metabolism. Journal of Clinical Investigation 198779 547-556. (doi:10.1172/ JCI112846)

41 Geary N. Pancreatic glucagon signals postprandial satiety. Neuroscience and Biobehavioral Reviews 199014 323-338. (doi:10.1016/S0149-7634(05)80042-9)

42 Gunawardana SC \& Piston DW. Insulin-independent reversal of type 1 diabetes in nonobese diabetic mice with brown adipose tissue transplant. American Journal of Physiology: Endocrinology and Metabolism 2015308 E1043-E1055. (doi:10.1152/ ajpendo.00570.2014)

43 Yoneshiro T, Aita S, Matsushita M, Kayahara T, Kameya T, Kawai Y, Iwanaga $\mathrm{T} \&$ Saito $\mathrm{M}$. Recruited brown adipose tissue as an antiobesity agent in humans. Journal of Clinical Investigation 2013123 3404-3408. (doi:10.1172/JCI67803)

44 Whittle A, Relat-Pardo J \& Vidal-Puig A. Pharmacological strategies for targeting BAT thermogenesis. Trends in Pharmacological Sciences 2013 34 347-355. (doi:10.1016/j.tips.2013.04.004)

Received 22 November 2016

Revised version received 5 April 2017

Accepted 21 April 2017 